\title{
The role of recognition in the induction of specific chitinases during mycoparasitism by Trichoderma harzianum
}

\author{
J. Inbar and I. Chet
}

Author for correspondence: J. Inbar. Tel: +972 8 481315. Fax: +9728468785.

Otto Warburg Center for Agricultural Biotechnology, The Hebrew University of Jerusalem, Faculty of Agriculture, Rehovot, Israel

\begin{abstract}
The induction of chitinolytic enzymes in the biocontrol agent Trichoderma harzianum during parasitism on Sclerotium rolfsii and the role of fungalfungal recognition in this process were studied. A change in the chitinolytic enzyme profile was detected during the interaction between the fungi, grown in dual culture on synthetic medium. Before coming into contact with each other, both fungi contained a protein with constitutive 1,4- $\beta-N$ acetylglucosaminidase activity. As early as $12 \mathrm{~h}$ after contact, the chitinolytic activity in S. rolfsii disappeared, while that of $\mathrm{T}$. harzianum (a protein with a molecular mass of $102 \mathrm{kDa}$, CHIT 102) greatly increased. After $24 \mathrm{~h}$ of interaction, the activity of CHIT 102 diminished concomitantly with the appearance of a $73 \mathrm{kDa}$ 1,4- $\beta-\mathrm{N}$-acetylglucosaminidase, which became clear and strong at $48 \mathrm{~h}$. This phenomenon did not occur if the 5 . rolfsii mycelium was autoclaved prior to incubation with $T$. harzianum, suggesting its dependence on vital elements from the host. Cycloheximide inhibited this phenomenon, indicating that de novo synthesis of enzymes is taking place in Trichoderma during these stages of the parasitism. A biomimetic system based on the binding of a purified surface lectin from the host $S$. rolfsii to nylon fibres was used to dissect the effect of recognition. An increase in CHIT 102 activity was detected, suggesting that the induction of chitinolytic enzymes in Trichoderma is an early event which is elicited by the recognition signal (i.e.

lectin-carbohydrate interactions). It is postulated that recognition is the first step in a cascade of antagonistic events which triggers the parasitic response in Trichoderma.
\end{abstract}

Keywords: Trichoderma, mycoparasitism, recognition, chitinases, lectins

\section{INTRODUCTION}

Parasitism is one of the mechanisms by which fungi from the genus Trichoderma antagonize other fungi (including plant pathogenic fungi), thereby serving as biocontrol agents of plant diseases (Baker, 1987; Chet, 1987, 1990). Parasitism by Trichoderma spp. is considered to be necrotrophic (destructive), whereby the relationship results in the destruction and death of the host fungus (Barnett \& Binder, 1973). Trichoderma spp. attach to the host hyphae by coiling, hooks or appressorium-like bodies and penetrate the host cell walls by secreting lytic enzymes such as 1,3- $\beta$-glucanase and chitinase (Elad et al., 1983).

\footnotetext{
Abbreviations: GICNAC, $N$-acetylglucosamine; 4-MU-(GICNAC), 4-methylumbelliferyl $\quad N$-acetyl- $\beta$-D-glucosaminide; 4-MU-(GICNAC) ${ }_{2}$, 4methylumbelliferyl $\beta$-D- $N, N^{\prime}$-diacetylchitobioside; 4-MU-(GICNAC), 4methylumbelliferyl $\beta$-D-N, $N^{\prime}, N^{\prime \prime}$-triacetylchitotriose.
}

The activity of these enzymes during the parasitism of Trichoderma harzianum on the soilborne plant pathogenic fungus Sclerotium rolfsii has been shown using fluorescein isothiocyanate (FITC)-conjugated lectins or Calcofluor White M2R. Localized cell-wall lysis was indicated by the appearance of fluorescence at points of interaction between the antagonist and its host. Enzymic activity and antagonism were diminished in the presence of cycloheximide (Elad et al., 1983).

A considerable amount of research has been carried out in recent years on the chitinolytic system of Trichoderma (De La Cruz et al., 1992; Haran et al., 1995; Harman et al., 1993; Lorito et al., 1993; Ulhoa \& Peberdy, 1991a, b, $1992,1993)$. It has been found to be a complex system consisting of six distinct enzymes. Using three different fluorescent analogue substrates, the system was found to be composed of two 1,4- $\beta-N$-acetylglucosaminidases 
(CHIT 102 and CHIT 73) and four endochitinases (CHIT 52, CHIT 42, CHIT 33 and CHIT 31) (Haran et al., 1995). All these enzymes were induced and excreted by $T$. harzianum (strain TM) during growth in liquid medium with chitin as sole carbon source. CHIT 102 could be detected intracellularly at a low constitutive level, even when Trichoderma was grown on glucose (Haran et al., 1995).

In all of these studies, the expression and regulation of chitinases in Trichoderma were studied in liquid cultures supplemented with different carbon sources, e.g. chitin, purified fungal cell walls, glucose or $N$-acetylglucosamine (GlcNAc) (De La Cruz et al., 1993; Haran et al., 1995; Ulhoa \& Peberdy, 1991a, 1993). Clearly, cell-wall-degrading enzymes, as well as other changes, e.g. morphological (coiling and appressorium formation) and cytological, were induced in both Trichoderma and the host fungi during the parasitic interaction (Benhamou \& Chet, 1993; Cherif \& Benhamou, 1990; Elad et al., 1983; Goldman et al., 1992, 1994; Lora et al., 1994; Schirmbock et al., 1994). However, which of the above-described Trichoderma chitinases is expressed during mycoparasitic interactions and what triggers their expression is still unknown. Recently, we were able to show that a lectin present on the cell wall of $S$. rolfsii serves as a recognition signal which induces coils and appressorium-like structure formation in T. harzianum (Inbar \& Chet, 1992, 1994). When a purified lectin from $S$. rolfsii was bound to nylon fibres in a biomimetic system that simulated the host hyphae, it specifically induced the formation of mycoparasite-related structures in Trichoderma (e.g. coils, hooks, appressorium-like bodies and hyphal loops). Secretion of adhesive material aiding in the establishment of the interaction of Trichoderma with the lectin-treated fibres was also observed (Inbar \& Chet, 1994).

In the present study, the induction of specific chitinases in $T$. barzianum during its parasitic interaction with $S$. rolfsii was studied by detection of chitinase activity using PAGE. The biomimetic system (Inbar \& Chet, 1992) was used to investigate the involvement of lectins in triggering chitinase activity in Trichoderma.

\section{METHODS}

Culture of organisms. Sclerotium rolfsii Sacc. type A, ATCC 26325, was maintained on a synthetic medium (SM; Okon et al., 1973). For lectin production and purification, $S$. rolfsii was grown in liquid SM supplemented with $5 \times 10^{-6} \mathrm{M}$ polyoxin D (Barak \& Chet, 1990). After $5 \mathrm{~d}$, the culture filtrate $(50 \mathrm{ml})$ was collected and dialysed for $24 \mathrm{~h}$ at $4^{\circ} \mathrm{C}$ against $20 \mathrm{mM}$ Tris $/ \mathrm{HCl}$ buffer ( $\mathrm{pH} 7 \cdot 0 ; 2 \times 5 \mathrm{l}$ ) (crude agglutinin). Trichoderma barzianum Rifai, T-Y, was grown on potato dextrose agar (PDA; Difco). Dual cultures were carried out by growing the fungi on a cellophane membrane which covered a $90 \mathrm{~mm}$ Petri dish containing SM supplemented with $0.2 \%(\mathrm{w} / \mathrm{v})$ glucose. Plates were inoculated with PDA strips $(3 \times 15 \mathrm{~mm})$ carrying mycelium of the fungi, placed parallel, $6 \mathrm{~cm}$ apart, and incubated at $28^{\circ} \mathrm{C}$ in the dark.

Enzyme production and identification of activity. At the indicated time, mycelium from the interaction zone, where Trichoderma parasitized $S$. rolfsii, was collected aseptically and washed with sterile distilled water. Washed mycelium, in sterile distilled water, was then homogenized by Ultra-Turrax (TP $18 / 10$, IKA-WERK) for $3 \mathrm{~min}$ at $4{ }^{\circ} \mathrm{C}$ and sonicated for $3 \mathrm{~min}$ at $4{ }^{\circ} \mathrm{C}$ with $50 \%$ pulses using a small microtip (Sonicator model W-375, Heat Systems-Ultrasonics). Finally, mycelium was homogenized for $3 \mathrm{~min}$ at $4{ }^{\circ} \mathrm{C}$ with a Heidolph R2R-50 homogenizer and centrifuged for $20 \mathrm{~min}$ at $20000 \mathrm{~g}$ at $4{ }^{\circ} \mathrm{C}$. The supernatant was collected and dialysed against distilled water $(4 \times 5 \mathrm{l})$ for $24 \mathrm{~h}$ at $4{ }^{\circ} \mathrm{C}$. Proteins were then freeze-dried and kept at $-70^{\circ} \mathrm{C}$ until use. Protein concentration was determined according to Bradford (1976) using the Bio-Rad protein assay dye reagent and BSA as a protein standard.

The effect of cycloheximide on the appearance of chitinolytic enzymes during the interaction between $T$. barzianum and $S$. rolfsii was tested by growing the Trichoderma alone in $90 \mathrm{~mm}$ Petri dishes containing SM, on a cellophane membrane as above, for $48 \mathrm{~h}$ at $28^{\circ} \mathrm{C}$. Membranes were then aseptically transferred to new dishes centrally divided into two sections, one containing SM and the other SM supplemented with cycloheximide $\left(20 \mu \mathrm{g} \mathrm{ml}^{-1}\right)$. Plates were then inoculated with $S$. rolfsii (on the unsupplemented SM) and further incubated under the same conditions. Proteins were obtained from the interaction zone at the indicated times, as described above.

For the identification of enzymic activity, proteins were prepared in Laemmli buffer (Laemmli, 1970) without 2mercaptoethanol. Proteins were separated by SDS-PAGE in $1.5 \mathrm{~mm}$ gels with 10 or $12 \%(\mathrm{w} / \mathrm{v})$ acrylamide in a Mini-Protean II cell (Bio-Rad) according to the manufacturer's instructions.

Chitinolytic enzymes were detected in situ using a set of three highly sensitive substrates that produce fluorescent products following enzymic hydrolysis: 4-methylumbelliferyl $N$-acetyl- $\beta$-D-glucosaminide [4-MU-(GlcNAc)]; 4-methylumbelliferyl $\beta$-D- $N, N^{\prime}$-diacetylchitobioside [4-MU(GlcNAc) ${ }_{2}$; $\quad 4$-methylumbelliferyl $\beta$-D-N, $N^{\prime}, N^{\prime \prime}$-triacetylchitotriose [4-MU-(GlcNAc) ${ }_{3}$ ] (all from Sigma). These compounds function as dimeric, trimeric and tetrameric substrates, respectively (Haran et al., 1995). Enzymes were reactivated by removing SDS, as per the casein/EDTA procedure described by McGraw \& Green (1990). Gels were washed twice for

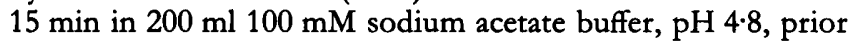
to the detection procedure. Enzyme activity was detected on gels as described by Tronsmo \& Harman (1993).

Immunological analysis. Proteins were separated by $12 \%$ SDSPAGE with 2-mercaptoethanol and electroblotted onto nitrocellulose membranes. Western blot analysis was performed as described by Ausubel et al. (1990) using rabbit polyclonal antibody raised against purified $42 \mathrm{kDa}$ endochitinase of $T$. barzianum strain P1 (kindly provided by Professor G. Harman, Cornell University, USA) or against CHIT 73 (Haran et al., 1995) (prepared in our laboratory by Mrs S. Haran). Detection was performed by enhanced chemiluminescence according to the manufacturer's instructions (Amersham).

Biomimetic system. Lectin from $S$. rolfsii was purified and bound to nylon fibres as previously described by Inbar \& Chet (1994). This biomimetic system was used to isolate the effect of recognition and to examine the role of the purified $S$. rolfsii lectin in the induction of $T$. barzianum chitinases during the parasitic interaction. $T$. barzianum was grown on a cellophane membrane covering SM supplemented with $0.2 \%(\mathrm{w} / \mathrm{v})$ glucose as described above, in the presence of lectin-treated nylon fibres, nylon fibres without lectin or no fibres at all. After $12 \mathrm{~h}$ incubation, mycelium was collected and protein production and chitinolytic enzymes were detected as above.

All experiments were carried out at least three times. Representative results are shown. 


\section{RESULTS}

\section{Chitinolytic enzyme profiles in a dual culture of T. harzianum and S. rolfsii}

Proteins from both $T$. harzianum and $S$. rolfsii were obtained during their interaction in dual culture at $0 \mathrm{~h}$ (just before contact) and at $12 \mathrm{~h}, 24 \mathrm{~h}$ and $48 \mathrm{~h}$ after contact. The proteins were separated and their chitinolytic activity detected as described in Methods.

Before contact, both fungi exhibited a single protein with constitutive chitinolytic activity (Fig. 1). The S. rolfsii chitinolytic protein (molecular mass of approximately $116 \mathrm{kDa}$ ) exhibited a high activity with all substrates tested (Fig. 1, lane 1). In T. harzianum, low constitutive chitinolytic activity could be detected before Trichoderma contacted $S$. rolfsii, from a protein of approximately $102 \mathrm{kDa}$ (Fig. 1, lane 2). This protein hydrolysed all the substrates tested, albeit at reduced rates, from 4-MU(GlcNAc) to 4-MU-(GlcNAc) ${ }_{2}$ and 4-MU-(GlcNAc) (not shown). For this reason, although it could be clearly seen in the original gel, it is not visible in Fig. 1. These data are in agreement with a previous study (Haran et al., 1995) where this enzyme was determined to be $1,4-\beta-N$ acetylglucosaminidase (CHIT 102). Twelve hours after contact between the $T$. harzianum and $S$. rolfsii colonies, the chitinolytic activity in $S$. rolfsii vanished, whereas that of CHIT 102 in Trichoderma dramatically increased (Fig. 1, lane 3$)$. This activity began to decrease $12 \mathrm{~h}$ later $(24 \mathrm{~h}$

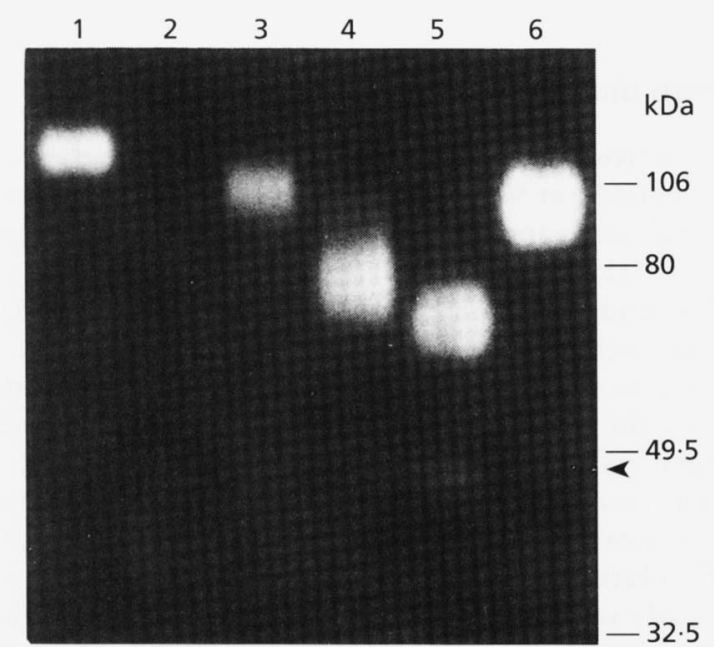

Fig. 1. Profile of chitinolytic enzymes ( $50 \mu \mathrm{g}$ per lane) obtained from a dual culture of $T$. harzianum and $S$. rolfsii grown on synthetic medium (SM) supplemented with glucose $(0.2 \%, w / v)$. Chitinolytic activity was detected following SDS-PAGE (10\% acrylamide) using 4-MU-(GICNAC) ${ }_{2}$ as the substrate. Lanes: 1, proteins produced by $S$. rolfsii before coming into contact with $T$. harzianum; 2 , proteins produced by $T$. harzianum before contacting $S$. rolfsii; 3,4 and 5 , proteins obtained from the interaction zone at $12 \mathrm{~h}, 24 \mathrm{~h}$ and $48 \mathrm{~h}$ post-contact, respectively; 6 , proteins produced by $T$. harzianum after $48 \mathrm{~h}$ incubation on solid SM with chitin as sole carbon source. The arrowhead indicates the position of the approximately $50 \mathrm{kDa}$ endochitinase which was more clearly seen in the original gel.

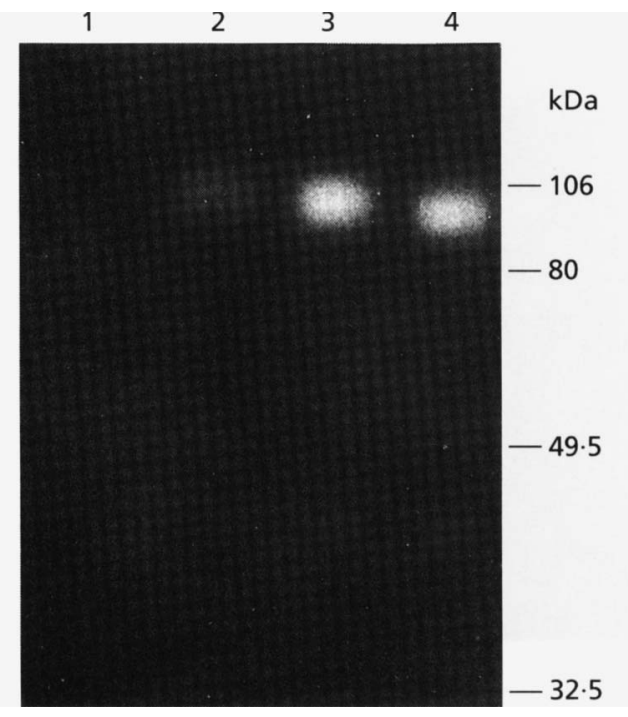

Fig. 2. Profile of chitinolytic enzymes ( $50 \mu \mathrm{g}$ per lane) obtained from a dual culture of $T$. harzianum and autoclaved mycelium of S. rolfsii. Chitinolytic activity was detected, following SDSPAGE (10\% acrylamide), using 4-MU-(GlcNAC) ${ }_{2}$ as the substrate. Lanes: 1, proteins obtained from the autoclaved mycelium of $S$. rolfsii; 2,3 and 4, proteins obtained from the interaction zone of $T$. harzianum with the autoclaved mycelium of $S$. rolfsii at $12 \mathrm{~h}, 24 \mathrm{~h}$ and $48 \mathrm{~h}$ post-contact, respectively.

after contact), concomitant to the appearance of two new proteins exhibiting chitinolytic activity: a $1,4-\beta-N$-acetylglucosaminidase with a molecular mass of $73 \mathrm{kDa}$, and an endochitinase of approximately $50 \mathrm{kDa}$ (Fig. 1, lanes 4 and 5). The latter enzyme exhibited very low activity with the trimeric and tetrameric substrates, and none with the dimeric one. These two chitinolytic enzymes remained active until Trichoderma totally covered the $S$. rolfsii colony (after $120 \mathrm{~h}$ ) (not shown). When $T$. barzianum was grown for $48 \mathrm{~h}$ on a solid SM supplemented with chitin $(0.2 \%$, $\mathrm{w} / \mathrm{v}$ ) as sole carbon source, CHIT 102 was strongly active together with weak activity of the $50 \mathrm{kDa}$ endochitinase (Fig. 1, lane 6). The above experiment was repeated, but this time the $S$. rolfsii mycelium was autoclaved prior to inoculating the plates with the antagonist and different results were obtained. For this experiment $S$. rolfsii was grown on the membrane until it reached the middle of the plate. Then, the membrane carrying the $S$. rolfsii mycelium was autoclaved, transferred to a new plate with SM and inoculated with $T$. barzianum. All other procedures were carried out as before. No chitinolytic activity was detected in $S$. rolfsii after autoclaving (Fig. 2, lane 1). Twelve hours after Trichoderma came into contact with the autoclaved mycelium of $S$. rolfsii, CHIT 102 was induced (Fig. 2, lane 2). However, in contrast to the results obtained in the living dual culture, in the interaction with the autoclaved $S$. rolfsii this enzyme remained active and became even more active with time, until $48 \mathrm{~h}$ post-contact, when the $50 \mathrm{kDa}$ endochitinase appeared weakly (Fig. 2, lane 4). These results are similar to those obtained when $T$. 


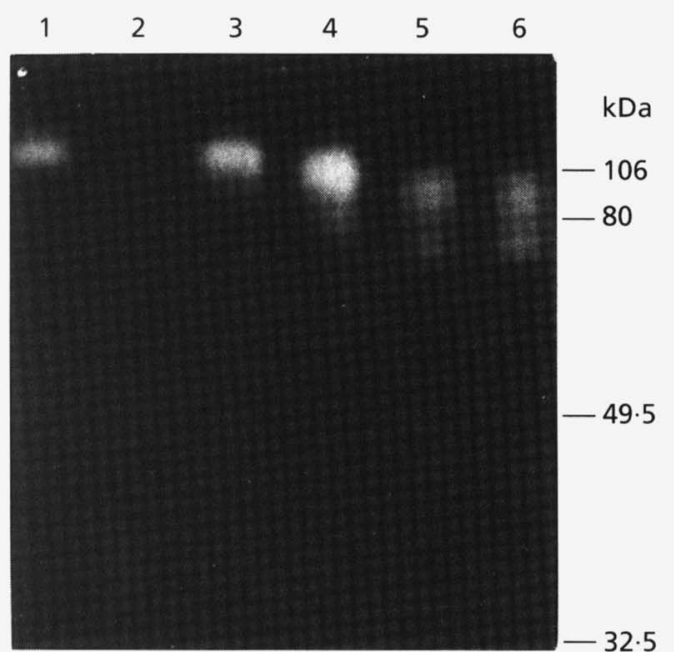

Fig. 3. Profile of chitinolytic enzymes $(50 \mu \mathrm{g}$ per lane) obtained from a dual culture of $T$. harzianum (grown on $\mathrm{SM}+$ cycloheximide, $20 \mu \mathrm{g} \mathrm{ml}^{-1}$ ) and S. rolfsii (grown on SM) in centrally divided dishes. Chitinolytic activity was detected following SDS-PAGE (12\% acrylamide) using 4-MU-(GICNAC) 2 as the substrate. Lanes: 1 , proteins obtained from the mycelium of $S$. rolfsii before contact with $T$. harzianum; 2 , proteins produced by $T$. harzianum before contact with $S$. rolfsii; 3, 4, 5 and 6 , proteins obtained from the interaction zone of $T$. harzianum with $S$. rolfsii at $6 h, 12 h, 24 h$ and $48 \mathrm{~h}$ postcontact, respectively.

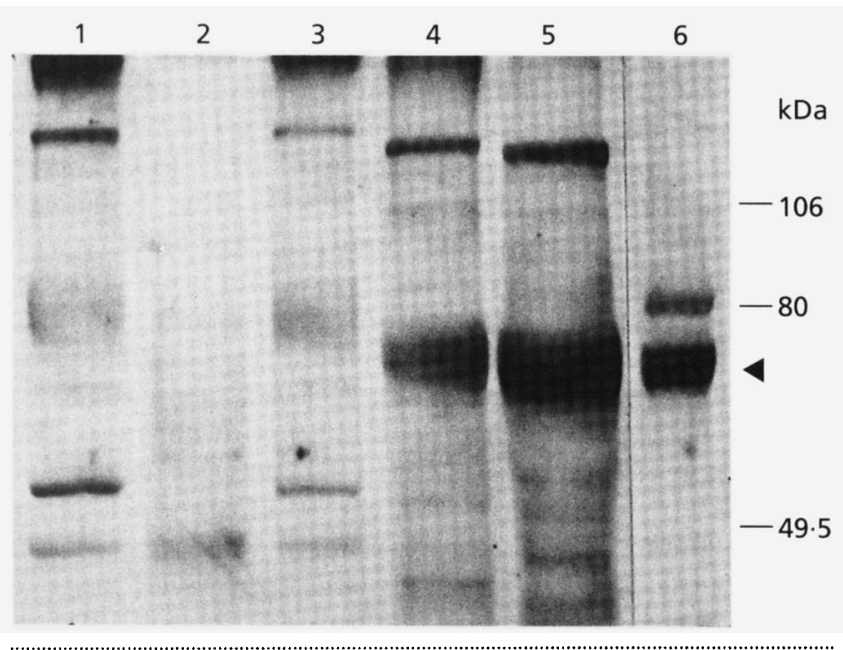

Fig. 4. Western blot analysis of SDS-PAGE ( $12 \%$ acrylamide) using rabbit polyclonal antibodies raised against CHIT 73 (a $73 \mathrm{kDa} \quad 1,4-\beta-N$-acetylglucosaminidase from $T$. harzianum) (Haran et al., 1995). Lanes containing $100 \mu \mathrm{g}$ protein are as in Fig. 1. The control lane (6) contains $20 \mu \mathrm{g}$ extracellular chitinolytic enzymes obtained from $T$. harzianum which was grown in liquid SM with chitin as sole carbon source. The arrowhead indicates the position of CHIT 73.

barzianum was grown on SM containing chitin (Fig. 1, lane 6), indicating the involvement of vital elements from the host $S$. rolfsii in this phenomenon, possibly proteases.

When Trichoderma was grown in dual culture in the presence of cycloheximide $\left(20 \mu \mathrm{g} \mathrm{ml}^{-1}\right)$, the appearance of

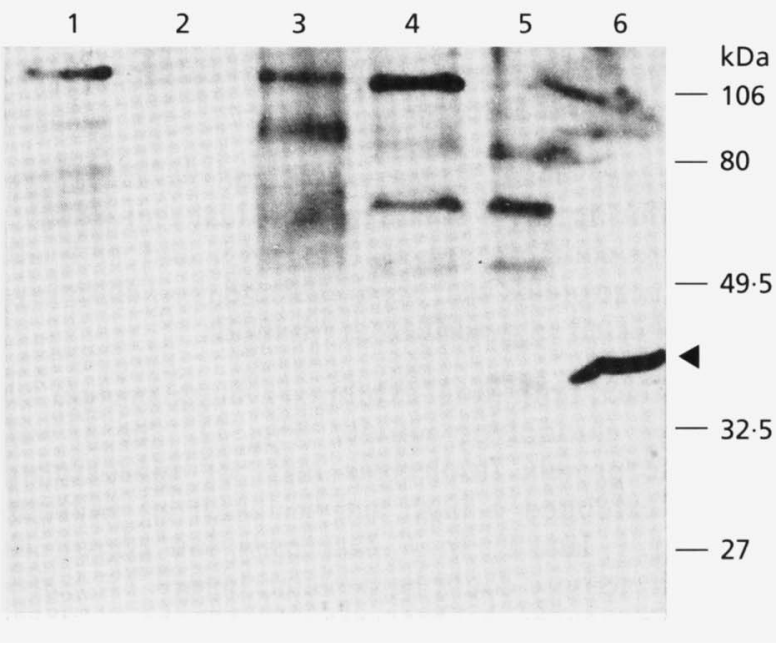

Fig. 5. Western blot analysis of SDS-PAGE ( $12 \%$ acrylamide) using rabbit polyclonal antibodies raised against CHIT 42, a purified endochitinase from $T$. harzianum strain P1. Lanes containing $100 \mu \mathrm{g}$ protein are as in Fig. 1. The control lane (6) contains $20 \mu \mathrm{g}$ extracellular chitinolytic enzymes obtained from $T$. harzianum which was grown in liquid SM with chitin as sole carbon source. The arrowhead indicates the position of CHIT 42.

its chitinolytic enzymes was inhibited (Fig. 3). Even after $48 \mathrm{~h}$ interaction, CHIT 102 was still present, while CHIT 73 was only faintly apparent. This suggests that enzymes in Trichoderma are synthesized de novo during these stages of the parasitism.

\section{Western blot analysis}

Proteins from dual cultures of $T$. harzianum and $S$. rolfsii were analysed at various times (as in Fig. 1) by Western blot analysis using polyclonal antibodies raised against CHIT 73 (Haran et al., 1995) (Fig. 4) and against a purified $42 \mathrm{kDa}$ endochitinase from $T$. harzianum (Fig. 5). A positive reaction to the anti-CHIT 73 antibodies was detected as early as $24 \mathrm{~h}$ after contact had been made between the fungi (Fig. 4, lane 4). The reaction became stronger and more defined at $48 \mathrm{~h}$ (Fig. 4, lane 5). No reaction could be detected in Trichoderma before contact with its host (Fig. 4, lane 2). These results suggest that the $73 \mathrm{kDa}$ chitinase present in this system is identical to the previously reported CHIT 73 against which the antibody was raised (Fig. 4, lane 6) (Haran et al., 1995). During the parasitic interaction between $T$. harzianum and $S$. rolfsii in dual culture, the $42 \mathrm{kDa}$ endochitinase was apparently either not expressed, or only expressed in small amounts. No reaction, or only a faint reaction, could be detected, even after $30 \mathrm{~min}$ exposure of the membrane (Fig. 5), confirming the results obtained from the chitinase activity gels.

Nonspecific reactions with both antibodies may result from the fact that proteins $(100 \mu \mathrm{g}$ per lane) were obtained from mycelium of both fungi grown in dual culture. Control lanes, containing $20 \mu \mathrm{g}$ T. harzianum extracellular 


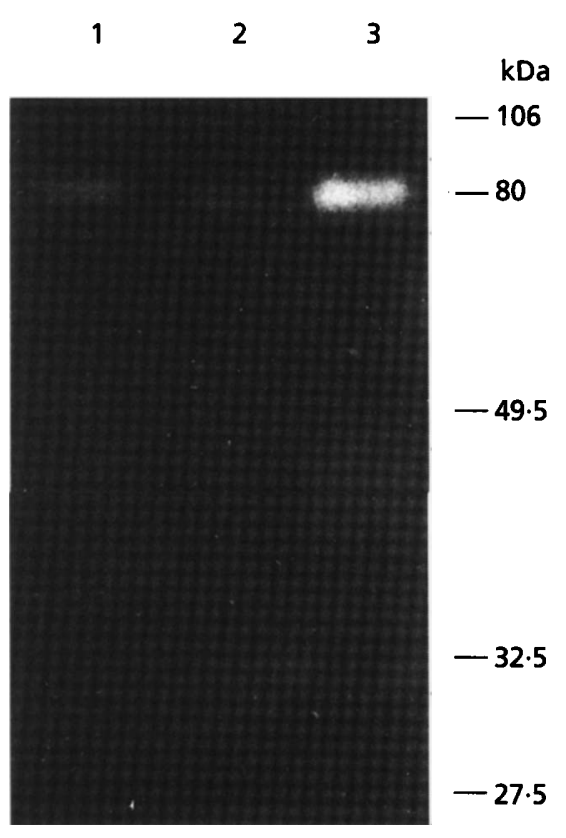

Fig. 6. Detection of chitinolytic activity in proteins $(25 \mu \mathrm{g}$ per lane) produced by $T$. harzianum grown in the biomimetic system in the presence or absence of variously treated nylon fibres. Lanes: 1, proteins obtained from $T$. harzianum grown on SM without nylon fibres; 2, proteins obtained from $T$. harzianum grown on SM, in the presence of untreated nylon fibres; 3 , proteins obtained from $T$. harzianum grown in the presence of nylon fibres coated with a purified lectin from $S$. rolfsii. Detection was carried out using 4-MU-(GICNAC) ${ }_{2}$ as the substrate.

proteins, exhibited only a minor nonspecific reaction or none at all (Figs 4 and 5, lane 6).

\section{Induction of chitinases in $T$. harzianum using the biomimetic system}

To check whether the purified $S$. rolfsii lectin which serves as a recognition signal for Trichoderma during its interaction with $S$. rolfsii (Inbar \& Chet, 1994) is also involved in the induction of chitinolytic enzymes in Trichoderma, T. harzianum was grown in Petri dishes with $\mathrm{SM}$ in the presence of the various nylon fibres as described in Methods. Proteins were produced and chitinolytic activity detected as before.

After $12 \mathrm{~h}$ incubation, a clear induction and increase in the activity of CHIT 102 was detected (Fig. 6, lane 3), as compared with the low constitutive activity in the control without nylon fibres (Fig. 6, lane 1). Growing Trichoderma in the presence of nylon fibres without lectin (Fig. 6, lane 2) resulted in no change in the activity of this enzyme as compared to the control. No induction of CHIT 102 could be detected when the purified $S$. rolsfi lectin, not bound to nylon fibres, was applied to colonies of $T$. barzianum via a Whatman paper saturated with the purified lectin (not shown). This observation suggests that the lectin serves as a signal only in association with the surface of the host's cell wall.

\section{DISCUSSION}

The involvement of fungal cell-wall-degrading enzymes (i.e. chitinases and $1,3-\beta$-glucanases) in the mycoparasitic action of Trichoderma spp. towards phytopathogenic fungi has been demonstrated previously (Benhamou \& Chet, 1993; Cherif \& Benhamou, 1990; Elad et al., 1982, 1983). Recently, Haran et al. (1995) reported the secretion of six different chitinolytic enzymes when $T$. harzianum (strain TM) was grown on liquid synthetic medium with chitin as sole carbon source. The present study was designed to determine which of the above described enzymes were active and how they were induced during mycoparasitism by Trichoderma. Chitinolytic enzymes were obtained from dual cultures of $T$. barzianum and $S$. rolfsii and detected in activity gels, as previously described by Haran et al. (1995). Our results revealed that as early as $12 \mathrm{~h}$ after contact between $T$. barzianum and $S$. rolfsii, activity of the constitutive 1,4- $\beta$ - $N$-acetylglucosaminidase (CHIT 102; Haran et al., 1995) is greatly increased. The presence of low constitutive activity of hydrolytic enzymes which are induced to increase their activity upon contact with the target has already been reported in several cases of hostparasite interactions (Benhamou et al., 1990; Kolattukudy, 1985; Metraux \& Boller, 1986). Kolattukudy (1985) suggested a model explaining the induction of the plantcuticle-hydrolysing enzyme cutinase in a plant pathogenic fungal spore by monomers generated from the polymer (cutin). On the other hand, the expression of chitinase, which is present at basal levels in healthy plants, increases dramatically during pathogen attack (Benhamou et al., 1990; Joosten \& De Wit, 1988; Metraux \& Boller, 1986). Twenty-four hours after contact between $T$. barzianum and $S$. rolfsii, CHIT 102 began to disappear and, concomitantly, CHIT 73 was activated. From then on, until the end of the incubation period, CHIT 73 was the major chitinolytic enzyme. This phenomenon was avoided by autoclaving $S$. rolfsii mycelium prior to its incubation with $T$. barzianum. In this case, as in the case of $T$. barzianum growing on SM with chitin as sole carbon source, CHIT 102 remained active up to $48 \mathrm{~h}$ after contact between $T$. barzianum and the sterile $S$. rolfsii mycelium. These results suggest that vital elements in the live mycelium of the host are responsible, at least in part, for this phenomenon. These might be proteases which are either already present or induced and released by $S$. rolfsii during the interaction with its antagonist $T$. barzianum. These putative proteases might digest CHIT 102 and at the same time activate CHIT 73. It was evident from the Western blot analysis that the $73 \mathrm{kDa}$ chitinase appearing at $48 \mathrm{~h}$ is identical to the CHIT 73 described by Haran et al. (1995). Activation of chitinases (microsomal and cytosolic) by both endogenous and exogenous proteases has been reported for a number of fungal species (Adams et al., 1993; Balasubramanian \& Manocha, 1992; Yanai et al., 1992). The apparent mechanism for chitinase regulation by proteolysis has been demonstrated by Yanai et al. (1992). Whether this is the case with the Trichoderma-S. rolfsii interaction and whether CHIT 102 is broken down to yield CHIT 73 are questions which warrant further research. Nevertheless, cycloheximide inhibited the 
above-described phenomenon, suggesting that de novo synthesis of enzymes (chitinases and/or proteases) is required for its occurrence.

Recognition, attachment and coiling of Trichoderma around its host hyphae are early events, preceding host hyphal damage (Benhamou \& Chet, 1993; Elad et al., 1983; Inbar \& Chet, 1994). Subsequently, a series of degradative events in the host begins (Benhamou \& Chet, 1993; Elad et al., 1983). Chitin oligomers released from the outer wall layers of the host were suggested to act as elicitors for synthesis of enzymes required for Trichoderma to penetrate the host cell wall (Benhamou \& Chet, 1993; Elad et al., 1982). Our results revealed that the induction of chitinolytic enzymes in Trichoderma during mycoparasitism is a very early event which is triggered by the recognition signal. Increased activity of CHIT 102 was detected when $T$. harzianum was grown on nylon fibres coated with the purified lectin of $S$. rolfsii. No chitin was present in this biomimetic system. Moreover, applying lectin which was not bound to fibres to colonies of $T$. harzianum revealed no increase in the activity of CHIT 102 as compared to controls. It is apparent from these and previous results (Inbar \& Chet, 1994) that the recognition signal triggers differentiation processes in Trichoderma leading to the formation of infection structures concomitant with the induction of a chitinolytic enzyme which is needed for penetration of the host cell wall. Recently, the expression of $e c h-42$ (a gene encoding one of the endochitinases produced by $T$. barzianum) was found to be strongly enhanced during interaction with Rbizoctonia solani. Chitin as sole carbon source, as well as light, also induced high levels of translation of this gene, suggesting its developmental regulation (Carsolio et al., 1994). Tunlid et al. (1992) suggested that in host-fungalparasite interactions, following recognition, differentiation processes which lead to the formation of various infection structures are accompanied by nuclear division and cytoskeletal rearrangement. These processes take place simultaneously with the secretion of extracellular hydrolytic enzymes and adhesins (Tunlid et al., 1992). This model was partially confirmed in our previous work (Inbar \& Chet, 1994). A possible relationship between the cytoskeleton and chitin synthase regulation during cellwall synthesis at the hyphal apex has been suggested by Wessels (1986). Adams et al. (1993) discussed the coordinated regulation of chitin synthase and chitinase and raised the question of whether cytoskeletal elements are also involved in the delivery and regulation of chitinases.

Schirmbock et al. (1994) demonstrated the parallel formation and synergism of hydrolytic enzymes and peptaibol antibiotics which are elicited in T. barzianum by cell walls of Botrytis cinerea. They suggested that the cascade of antagonistic events might be regulated by a common mechanism. Lora et al. (1994) investigated changes in gene expression patterns in Trichoderma elicited by pathogenic fungi. They speculated that oligosaccharides containing GlcNAc, which are generated by the partial degradation of fungal cell walls, act as elicitors which might trigger a general antifungal response in Trichoderma. It is evident from the present work that different chitinases are activated at different times during mycoparasitism by Trichoderma. Based on our results, we suggest that an earlier event, namely the recognition event which is mediated by lectin-carbohydrate interactions, serves as a signal that triggers a general parasitic response in Trichoderma. This response consists of morphological changes (i.e. coiling, appressorium formation, etc.) which involve cytoskeletal rearrangements and nuclear division. At the same time, induction of cell-wall-hydrolysing enzymes (e.g. chitinases) and changes in other related proteins, e.g. induction of cell-wall proteins (Lora $e t$ al., 1994), or suppression of others (Goldman et al., 1992), take place. Chitin oligomers or monomers may regulate further expression of the system as the process progresses.

\section{ACKNOWLEDGEMENTS}

We would like to express our thanks to Professor G. Galili of the Department of Plant Genetics, the Weizmann Institute of Science, and Professor Y. Hadar of the Faculty of Agriculture, The Hebrew University of Jerusalem, for their helpful ideas and discussions. We thank Professor G. Harman of Cornell University, USA, for providing us with the antibodies against CHIT 42, and Mrs S. Haran for providing the anti-CHIT 73 antibodies. This research was supported by the Binational Agricultural Research and Development Fund (BARD) and by the Chais Family Foundation, USA.

\section{REFERENCES}

Adams, D. J., Causier, B. E., Mellor, K. J., Keer, V., Milling, R. \& Dada, J. (1993). Regulation of chitin synthase and chitinase in fungi. In Chitin Enzymology, pp. 15-25. Edited by R. A. A. Muzzarelli. Ancona: European Chitin Society.

Ausubel, F. M., Brent, R., Kingston, R. E., Moore, D. D., Seidman, J. G., Smith, J. A. \& Struhl, K. (editors) (1990). Current Protocols in Molecular Biology. New York: John Wiley.

Baker, R. (1987). Mycoparasitism: ecology and physiology. Can J Plant Pathol 9, 370-379.

Balasubramanian, R. \& Manocha, M. S. (1992). Cytosolic and membrane-bound chitinases of two mucoraceous fungi: a comparative study. Can J Microbiol 38, 331-338.

Barak, R. \& Chet, I. (1990). Lectin of Sclerotium rolfsii. Its purification and possible function in fungal interaction. $J$ Appl Microbiol 69, 101-112.

Barnett, H. L. \& Binder, F. L. (1973). The fungal host-parasite relationship. Annu Rev Phytopatbol 11, 273-292.

Benhamou, N. \& Chet, I. (1993). Hyphal interactions between Trichoderma barzianum and Rbizoctonia solani: ultrastructure and gold cytochemistry of the mycoparasitic process. Phytopathology 83, 1062-1071.

Benhamou, N., Joosten, M. H. A. J. \& De Wit, P. J. G. M. (1990). Subcellular localization of chitinase and of its potential substrate in tomato root tissue infected by Fusarium oxysporum f. sp. radicislycopersici. Plant Pbysiol 92, 1108-1120.

Bradford, M. M. (1976). A rapid and sensitive method for quantitation of microgram quantities of protein utilizing the principle of protein-dye binding. Anal Biochem 72, 248-254.

Carsolio, C., Gutierrez, A., Jimenez, B., Van Montagu, M. \& Herrera-Estrella, A. (1994). Characterization of ech-42, a Trichoderma barzianum endochitinase gene expressed during mycoparasitism. Proc Natl Acad Sci US A 91, 10903-10907. 
Cherif, M. \& Benhamou, N. (1990). Cytochemical aspects of chitin breakdown during the parasitic action of a Trichoderma sp. on Fusarium oxysporum f. sp. radicis-lycopersici. Pbytopathology 80, 1406-1414.

Chet, I. (1987). Trichoderma - application, mode of action, and potential as biocontrol agent of soilborne plant pathogenic fungi. In Innovative Approaches to Plant Disease Control, pp. 137-160. Edited by I. Chet. New York: John Wiley.

Chet, I. (1990). Mycoparasitism-recognition, physiology and ecology. In New Directions in Biological Control: Alternatives for Suppressing Agricultural Pests and Diseases, pp. 725-733. Edited by R. Baker \& P. Dunn. New York: Alan R. Liss.

De La Cruz, J., Hidalgo-Gallego, A., Lora, J. M., Benitex, T., PintorToro, J. A. \& Llobell, A. (1992). Isolation and characterization of three chitinases from Trichoderma barzianum. Eur J Biochem 206, 859-867.

De La Cruz, J., Rey, M., Lora, J. M., Hidalgo-Gallego, A., Dominguez, F., Pintor-Toro, J. A., Llobell, A. \& Benitez, T. (1993). Carbon source control on $\beta$-glucanases, chitobiase and chitinase from Trichoderma barzianum. Arch Microbiol 159, 316-322.

Elad, Y., Chet, I. \& Henis, Y. (1982). Degradation of plant pathogenic fungi by Trichoderma harzianum. Can J Microbiol 28, 719-725.

Elad, Y., Chet, I., Boyle, P. \& Henis, Y. (1983). Parasitism of Trichoderma spp. on Rhizoctonia solani and Sclerotium rolfsiiscanning electron microscopy and fluorescence microscopy. Phytopathology 73, 85-88.

Goldman, G. H., Geremia, R. A., Caplan, A. B., Vila, B., Villarroel, R., van Montagu, M. \& Herrera-Estrella, A. (1992). Molecular characterization and regulation of the phosphoglycerate kinase gene from Trichoderma viride. Mol Microbiol 6, 1231-1242.

Goldman, G. H., Vasseur, V., Contreras, R. \& van Montagu, M. (1994). Sequence analysis and expression studies of a gene encoding a novel serine + alanine-rich protein in Trichoderma harzianum. Gene 144, 113-117.

Haran, S., Schickler, H., Oppenheim, A. \& Chet, I. (1995). New components of the chitinolytic system of Trichoderma harzianum. Mycol Res 99, 441-446.

Harman, G. E., Hayes, C. K., Lorito, M., Broadway, R. M., Di Pietro, A., Peterbauer, C. \& Tronsmo, A. (1993). Chitinolytic enzymes of Trichoderma barzianum: purification of chitobiosidase and endochitinase. Phytopathology 83, 313-318.

Inbar, J. \& Chet, I. (1992). Biomimics of fungal cell-cell recognition by use of lectin-coated nylon fibers. $J$ Bacteriol 174, 1055-1059.

Inbar, J. \& Chet, I. (1994). A newly isolated lectin from the plant pathogenic fungus Sclerotium rolfsii: purification, characterization and its role in mycoparasitism. Microbiology 140, 651-657.

Joosten, M. H. A. J. \& De Wit, P. J. G. M. (1988). Identification of several pathogenesis-related proteins in tomato leaves inoculated with Cladosporium fulvum (Syn. Fulvia fulva) as $\beta$-1,3-glucanases and chitinases. Plant Pbysiol 89, 945-951.

Kolattukudy, P. E. (1985). Enzymatic penetration of the plant cuticle by fungal pathogens. Annu Rev Phytopatbol 23, 223-250.
Laemmli, U. K. (1970). Cleavage of structural proteins during the assembly of the head of bacteriophage T4. Nature 227, 680-685.

Lora, J. M., De La Cruz, J., Benitez, T., Llobell, A. \& Pintor-Toro, J. A. (1994). A putative catabolite-repressed cell wall protein from the mycoparasitic fungus Trichoderma barzianum. Mol \& Gen Genet 242, 461-466.

Lorito, M., Harman, G. E., Hayes, C. K., Broadway, R. M., Woo, S. L. \& Di Pietro, A. (1993). Chitinolytic enzymes produced by Trichoderma barzianum. II. Antifungal activity of purified endochitinase and chitobiosidase. Phytopatbology 83, 302-307.

McGraw, B. R. \& Green, M. (1990). Enhanced removal of detergent and recovery of enzymatic activity following sodium dodecyl sulfate-polyacrylamide gel electrophoresis : use of casein in gel wash buffer. Anal Chem 189, 68-74.

Metraux, J. P. \& Boller, T. (1986). Local and systemic induction of chitinase in cucumber plants in response to viral, bacterial and fungal interactions. Pbysiol Mol Plant Pathol 28, 161-169.

Okon, Y., Chet, I. \& Henis, Y. (1973). Effects of lactose, ethanol and cycloheximide on the translation pattern of radioactive compounds and on sclerotium formation of Sclerotium rolfsii. J Gen Microbiol 74, 251-258.

Schirmbock, M., Lorito, M., Yong-Li, W., Hayes, C. K., ArisanAtac, I., Scala, F., Harman, G. E. \& Kubicek, C. P. (1994). Parallel formation and synergism of hydrolytic enzymes and peptaibol antibiotics, molecular mechanisms involved in the antagonistic action of Trichoderma harzianum against phytopathogenic fungi. Appl Environ Microbiol 60, 4364-4370.

Tronsmo, A. \& Harman, G. E. (1993). Detection and quantification of $N$-acetyl- $\beta$-D-glucosaminidase, chitobiosidase, and endochitinase in solutions and on gels. Anal Biocbem 208, 74-79.

Tunlid, A., Jansson, H. B. \& Nordbring-Hertz, B. (1992). Fungal attachment to nematodes. Mycol Res 6, 401-402.

Ulhoa, C. J. \& Peberdy, J. F. (1991a). Purification and characterization of an extracellular chitobiase from Trichoderma barzianum. Curr Microbiol 23, 285-289.

Ulhoa, C. J. \& Peberdy, J. F. (1991b). Regulation of chitinase synthesis in Trichoderma harzianum. J Gen Microbiol 137, 2163-2169.

Ulhoa, C. J. \& Peberdy, J.F. (1992). Purification and some properties of the extracellular chitinase produced by Trichoderma barzianum. Enzyme Microb Technol 14, 236-241.

Ulhoa, C. J. \& Peberdy, J. F. (1993). Effect of carbon sources on chitobiase production by Trichoderma harzianum. Mycol Res 97, 45-48.

Wessels, J. G. H. (1986). Cell wall synthesis in apical hyphal growth. Int Rev Cytol 104, 37-39.

Yanai, K., Takaya, N., Kojima, N., Horiuchi, H., Ohta, A. \& Takagi, M. (1992). Purification of two chitinases from Rhizopus oligosporus and isolation and sequencing of the encoding genes. J Bacteriol 174, 7398-7406.

Received 30 May 1995; revised 15 July 1995; accepted 21 July 1995. 